\title{
DIFFERENTIAL PHYTOCHEMICAL CONSTITUENTS OF BRASSICA NAPUS L. CULTIVARS (REANDY, SULTAN AND HEROS) AS A NATURAL SOURCES OF BIO-FUELS
}

\author{
Ahmed Ab.Jabbar ${ }^{1}$, Venos S. Abdullah², Bahar J. Mahmood ${ }^{3}$ \\ ${ }^{1}$ Medical Laboratory Techniques Dep., Erbil Technical Health College, \\ Erbil Polytechnic University \\ ${ }^{2}$ Physiotherapy Department, Erbil Technical Health College, \\ Erbil Polytechnic University \\ ${ }^{3}$ Field crops Dep., Agriculture Engineering Sciences College, \\ Salahaddin University/Erbil, Iraq. \\ Email:ahmed.abuljabbar@epu.edu.iq
}

\begin{abstract}
The current work aims to study three seed cultivars of rapeseed (Brassica napus), as well as trying to provide a phytochemical insight of different rapeseed cultivars to be potentially cultivated as natural alternative hydrocarbon sources to petroleum hydrocarbons. The three seed cultivars, namely Heros, Sultan and Reandy were purchased from Britain, India and Sweden, respectively. After being cultivated, the seeds were collected, dried, and crushed. Oils from the crushed seeds were extracted with n-hexane as a solvent, and the attained oils were analyzed by GC-MS. The results showed that the tested oil seeds exhibited valuable phytochemical constituents, possessing increased percentages of long chain hydrocarbons. The 2,4-Decadinal (E,E)-(CAS) was the superior phytochemical compounds in Heros (18.73\%) and sultan (29.35\%) seed oils, However, it was the second prevalent compound in Reandy seed oils. Also, percentage of the hydrocarbons content of the reandy seed genotype was $(39.91 \%)$ higher than that of the Sultan (17.78\%) seed oils. The most prevalent fatty acids were shown to be 9Octadecenoic acid all the three tested gen verities. Based on the obtained data, Good hydrocarb plant yields can be offered by Heros and reandy cultivars. Also as a seed oil, could be considered as efficient plant oil for the industrial utilization as nonedible oils or in the biodiesel production as a low emission renewable energy.
\end{abstract}

Keywords: B. napus, Secondary Organic compounds, Renewable energy, GC-MS.

Received: $26 / 6 / 2020$, Accepted: 12/9/2020

\section{INTRODUCTION}

Brassica napus is a flowering plant with rich oily seeds. It's well-Known plant because of its high organic contents as it belongs to the family Brassicaceae (Friedt and Snowdon, 2009). A group of the cultivated medicinal food plants commonly found in Middle Asia, North Africa and West Europe. Rapeseeds is their common name, originates from its oily seeds being used as source of nutritional and medicinal agents (Talbot, 2015). Developing of a genotype with an increased hydrocarbon plant yields become a potential target for plant breeders due to the fact that plants with high erucic acid, and glucosinolates contents possess some barriers to be used as food for certain animals and industrially its extracted oils must be 
refined before releasing to markets as these phytochemicals shown to responsible for bitterness taste and digestive disorders. Also to provide more hydrocarbon yields as an alternative to conventional hydrocarbon for biofuel production (Soodabeh Saeidnia, 2012). In recent decades, demands for new natural products as medicinal and aromatic agents attracted scientist to conduct more plant explorations. (Cartea et al., 2019).

The extraction of oils from those plant seeds was conducted as a result of their importance as a second-generation source. Essential oils are natural compounds produced by various plant families, as a secondary by-product of metabolism. Hydrocarbons, aldehydes, terpenes, esters, polyphenols, glycosides, flavonoids, sterols, triterpene alcohols, proteins and carbohydrates are classified under those organic compounds. Studies of plant essential oils have proven their antioxidant and anti-inflammatory efficiency (Kaiani et al., 2019). The presence of the same essential oil contents for Brassica plant family majorly juncea and napus species made them possessing a great potential as biomedicine agents that works significantly against several bacterial, fungal, and viral pathogens (Sharma et al., 2017).

Researchers have proven that certain plants can synthesize hydrocarbons with various carbon chains and thus could be utilized in the production of bio-fuels as alternative to depleted fossil fuels ( $\mathrm{Fu}$ et al., 2015). These findings led to series attempts to find out and use alternative form of energy. Most communities throughout the world relay on natural underground resources and scientists have claimed that about $95 \%$ of the world energy supplied from Natural gas, coal and oil (all fossilized photosynthetic products) which will be peak out by 2050 (Abas. et al., 2015). Hydrocarbon-like material, a renewable and self-sustaining bio-energy would only be able to compete with the fossil fuel resources.

Petro farming, a term used for developing petroleum plantations and growing green factories for the production of hydrocarbon-like material from special plant crops after cultivation. Growing hydrocarbon yielding plants could become a good substitute to the conventional hydrocarbons. The increasing dependence on oil imports and lack of biofuel property content in majority of plants are enough to apply petro forming by many countries (Kalita, 2008). Different analyzing methods applied aiming to explore the possible features of certain biomass as an energy crops and botanochemicals to be used a renewable energy.

One of these methods is Gas chromatography-mass spectroscopy (GC-MS), the preferably used tool due to its capabilities to quantitatively ant qualitatively determine certain phytochemicals in a very precise manner from a mixture of different natural organic compounds (Jayalakshmi et al., 2018). The present study investigates the phytochemicals and hydrocarbon contents of various genotypes of Brassica napus by extracting their seed oils and analyzing them through GC-MS. Also, aims to provide inside chemical view for persuasive workers in developing petroleum plantations. Hoping to aid them in breeding a plant genotype with the highest hydrocarbon yielding to be used as renewable source of energy. 
Mesopotamia J. of Agric.

Vol. (48) No. (3) 2020
ISSN: 2224 - 9796 (Online)

ISSN: 1815 - $316 \mathrm{X}$ (Print)

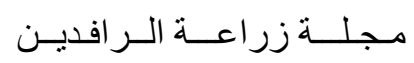

المجلد (48) العدد (3) (3) 2020

\section{MATERIALS AND METHODS \\ Plant cultivation and Sample preparation}

The Reandy seeds of Brassica napus L., Heros, and sultan cultivars, were brought from Sweden, England and India, respectively. The identification and authentication of the purchased plant seeds Are done by Department of field crop / College of Agricultural engineering and the seeds were cultivated during the winter growing season at Gerda rasha Research Field (latitude $36.11^{\circ} \mathrm{N}$, longitude $44.01^{\circ} \mathrm{E}$, Altitude $406.0 \mathrm{~m}$ above sea level) / College of Agriculture Engineering Science / University of Salahaddin / Erbil. Plant seeds were freshly collected and stored for subsequent analysis (Abdullah et al., 2019). Figure (1) shows the field experiment and the genotypes seeds.

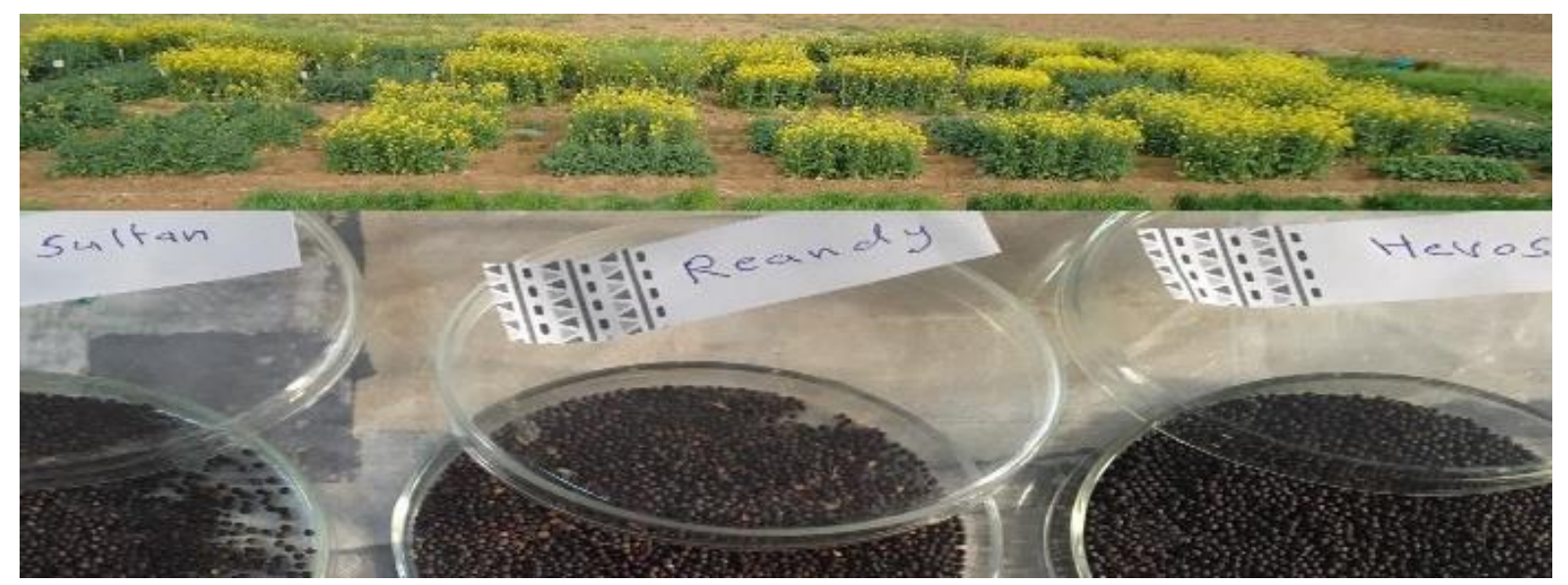

Figure 1. Rapeseed cultivations and then collection of fresh seeds of Sultan, Reandy and Heros variety of Brassica napus.

The collected seeds were crushed, using a pestle and mortar, to increase surface area. The plant material preparation was sufficient to fill the porous cellulose thimble (in our experiments we use an average of $14 \mathrm{~g}$ of thyme in a $25-\mathrm{x}$ 80 -mm thimble). The solvent (n-hexane) was added to a round bottom flask, which is attached to a Soxhlet extractor and condenser on an iso-mantle. The crushed seeds was loaded into the thimble, which is placed inside the Soxhlet extractor. The side arm was lagged with glass wool. The solvent is heated at $70^{\circ} \mathrm{C}$ using the isomantle and will begin to evaporate, moving through the apparatus to the condenser. The condensate then drips into the reservoir containing the thimble. Once the level of solvent reached the siphon it pours back into the flask and the cycle went on again. The process should run for a total of 3 hours at $70 \mathrm{C}^{\circ}$ (Yeddes et al., 2012). As the process has finished, the hexane solvent was recovered using a rotary evaporator, leaving a small yield of extracted plant oils (about 2 to $3 \mathrm{ml}$ ) in the glass bottom flask. Afterward, the essential oil was collected in tightened vials and stored in a refrigerator for later analysis (Verran et al., 2014).

The oil yield was calculated as follows:

Oil yield \%= (weight or volume of oil/ weight of seed used) X100 


\section{Chemical Composition Detection}

Investigating the extracted oils was accomplished using Shimadzu Model QP2010 GC coupled with MS. The GC equipped with HP-5 MS (5\% phenylmethyl siloxane), capillary column $(30 \mathrm{~m} \times 0.25 \mathrm{~mm}$ i.d., film thickness $0.25 \mu \mathrm{m})$ in a tempreture range of $60^{\circ} \mathrm{C}$ (for $2 \mathrm{~min}$.) to $250{ }^{\circ} \mathrm{C}$ for 10 minutes with a heating rate of $20^{\circ} \mathrm{C} / \mathrm{min}$ under $1.61 \mathrm{ml} /$ minute flow of helium gas. The ion source maintained at $250{ }^{\circ} \mathrm{C}$ with electron energy $70 \mathrm{eV}$. Each oil was then dissolved in methanol and then $1 \mu 1$ injected in the column. Based on the Wiley library, the unknown component was recognized based on the comparison of their mass spectrum with the spectrum of the known components. Chemical identifications including names, chemical structure and molecular weight of sample contents were eventually obtained following the same procedure established by (Sparkman, 2005).

\section{RESULTS AND DISCUSSION}

The phytochemical study of Heros, sultan and Reandy genes showed different quantitative and qualitative analysis (Table1). The varieties (Heros, Sultan, and Reandy) contained 19, 20 and 14 kinds of compounds, respectively relating to $100 \%$ in their total volatiles, as illustrated in Figure 2, 3, and 4.

Collectively, a total of 53 different compounds were identified, could be classified as Aldehyde, esters, fatty acids, Hydrocarbon, terpenoid and alcohol (table2). According to the obtained data, 5 phytochemicals were common to the three varieties, including 2,4-Decadinal (E,E)-(CAS), Hexadecan2,6,10,14tetramethyl-(CAS), Tetratriacontane (CAS), 9-Octadecenoic acid (Z)-(CAS), Hexadecanoic acid 2-hydroxy-1-hydroxymethyl was founded. The percentages of the compound 2,4-Decadinal (E, E) (CAS) were 29.35, 18.73 and $9.86 \%$ for the Sultan, Heros and Reandy seed oils, respectively. Hexadecane 2,6,10,14tetramethyl-(CAS) percentages were 27.71, 18.54 and $6.83 \%$ for the Reandy, Heros and sultan seed oils, respectively. Tetratriacontane (CAS) percentage were 2.49, 2.25 and $1.87 \%$ for the Reandy, Heros and sultan seed oils, respectively. The fatty acid 9-Octadecenoic acid (oleic acid) percentage were 9.91, 7.70 and $7.41 \%$ for the Reandy, Heros and Sultan seed oils, respectively. The same result was reported by (Cartea et al., 2019). Oleic acids as the most common fatty acid in all three seed genes of Rapeseed. Palmitic acid was also present in the three varieties. These fatty acid are known to have many medicinal and industrial values (Senthilkumar et al., 2012).

Hexadecanoic acid 2-hydroxy-1-(hydroxyl methyl) percentage were 12.43, 11.52 and $4.36 \%$ for Heros, Sultan and Reandy respectively. The 2, 4-Decadinal (E,E)-(CAS) was the most abundant compound in Heros (18.73\%) and Sultan (29.35\%) genes. While Reandy genes had Hexadecan2,6,10,14-tetramethyl-(CAS) as the most common phytochemical $(27.71 \%)$ in their seed oils. Chemical content differenciality of some genotypes of same plant family, may be due to the fact that each genotype possess a variety of metabolism actions or defense system (Jianmei et al., 1997). 
Mesopotamia J. of Agric.

Vol. (48) No. (3) 2020
ISSN: 2224 - 9796 (Online)

ISSN: 1815 - 316 X (Print)

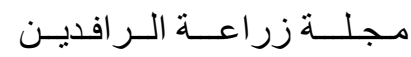
المجلد (48) العدد (3) 2020

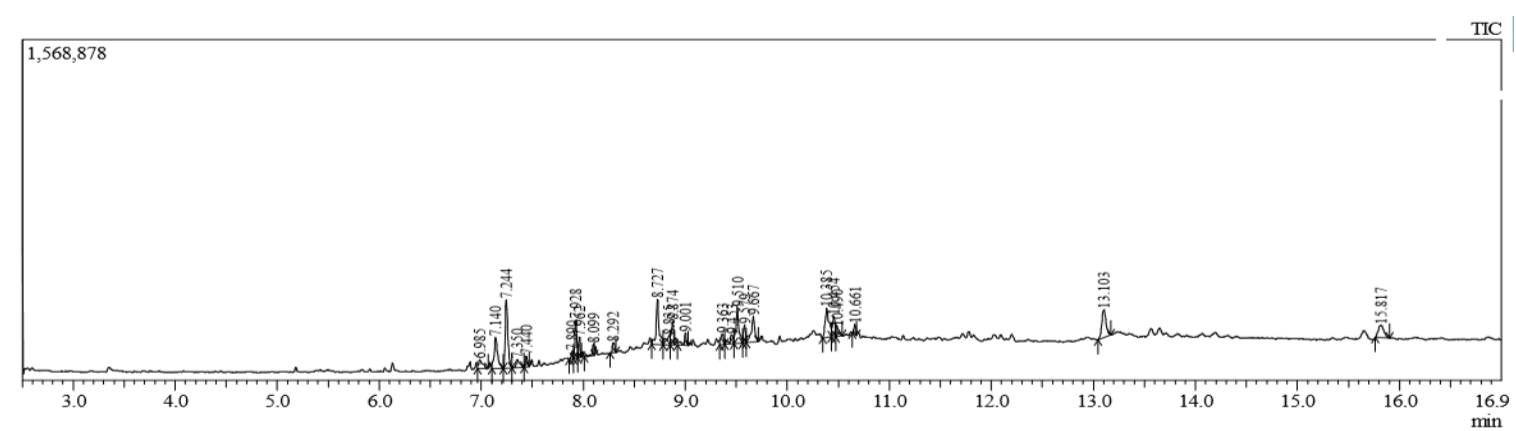

Figure 2: Typical chromatographic profile of the volatile fractions (Y-axis) at different times ( $\mathrm{X}$-axis ) isolated from Heros genotype

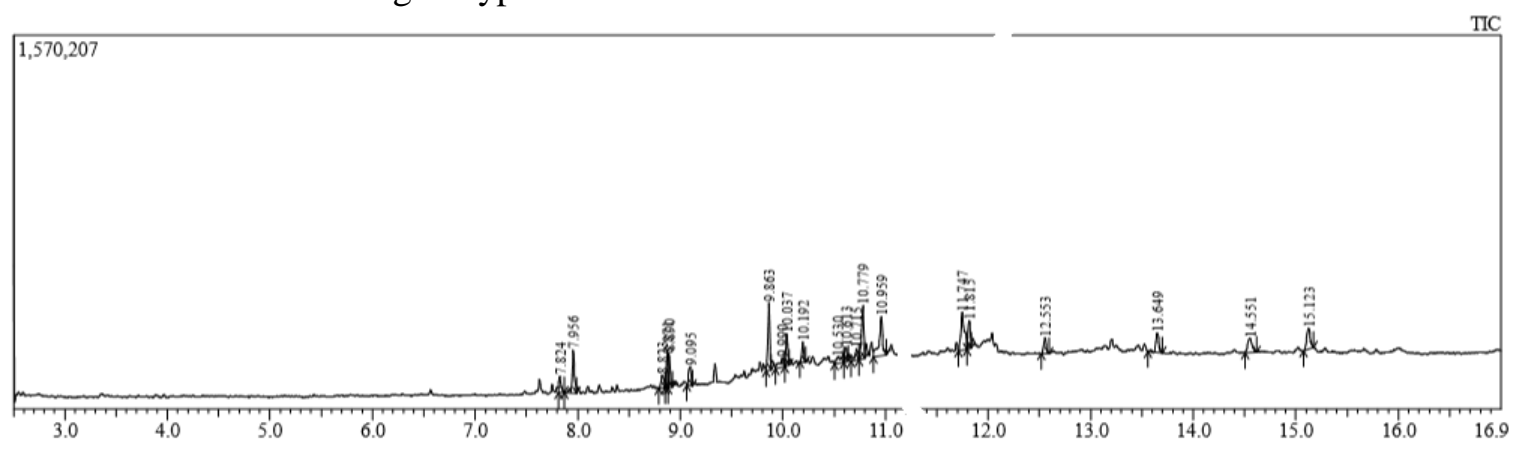

Figure 3: Typical chromatographic profile of the volatile fractions (Y-axis) at different times (X-axis ) isolated from Reandy genotype

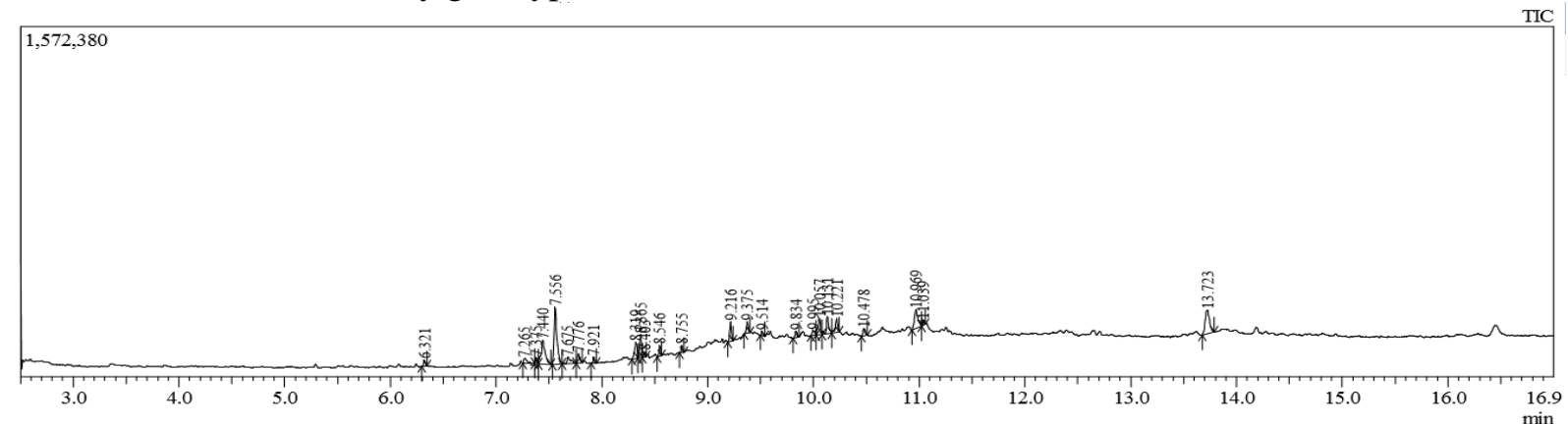

Figure 4: Typical chromatographic profile of the volatile fractions (Y-axis) at different times (X-axis) isolated from Sultan genotype.

The data analysis of Heros variety showed presence of some compounds like Pentadecane,2,6,10,14-tetramethyl -(CAS), Dotriacontane (CAS), Pentadecanoic acid (CAS) and Tetrapentacontane, etc. that were not found in sultan and Reandy varieties. While, Sultan genotype had Nonanal (CAS), Nonanal (CAS), and Isochiapin, etc. as differential chemical compounds that were not present in Heros and Reandy. The Reandy seeds analysis showed chemicals like 2,5-Cyclohexadiene-1,4-dione,2,6-bis(1,1-dimethyl), and Tridecanoic acid (CAS), etc.that were absent in Heros and sultan Table (1).

The most abundant organic class compounds of Heros were Hydrocarbons, aldehydes and terpenoids accounting for $76.09 \%$ of the total seeds oil content. Those compounds have shown to be important source of many industrial products (Boszoradova et al., 2011). High biological yields of Heros also reported by(Naghavi et al., 2015). The evaluation showed that the most available organic class compounds of sultan were aldehyde, hydrocarbon and terpenoid accounting for $69.46 \%$ of the total seeds oil chemical content, including Isochiapin B as valuable terpenoid, were shown to have antimicrobial, antioxidant, antiinsect and anticancer effects (Değirmenci et al., 2020). 
Mesopotamia J. of Agric.

Vol. (48) No. (3) 2020
ISSN: 2224 - 9796 (Online)

ISSN: 1815 - $316 \mathrm{X}$ (Print)
مجلــــة زر اعـــة الــر افـديـن

المجلد (48) العدد (3) 2020

Table (1): Shows GC-MS phytochemical constituents of Heros Sultan and Reandy genes of Brassica napus

\begin{tabular}{|c|c|c|c|c|c|c|}
\hline \multirow[t]{2}{*}{ No. } & \multirow[t]{2}{*}{ Fatty acids } & \multirow{2}{*}{$\begin{array}{l}\text { Molecular } \\
\text { formula }\end{array}$} & \multirow{2}{*}{$\begin{array}{c}\text { olecular } \\
\text { weight } \\
\mathrm{g} / \mathrm{mol}\end{array}$} & \multicolumn{3}{|c|}{ Relative abundance $\%$} \\
\hline & & & & Heros & Sultan & Reandy \\
\hline 1. & 2-decenal,E-(CAS) & $\mathrm{C}_{10} \mathrm{H}_{18} \mathrm{O}$ & 154.25 & 2.25 & 1.62 & - \\
\hline 2. & 2,4-Decadinal.(E,E)-(CAS) & $\mathrm{C}_{10} \mathrm{H}_{16} \mathrm{O}$ & 152.23 & 18.73 & 29.35 & 9.86 \\
\hline 3. & Octadecanicacid,2-oxo-methyl ester(CAS) & $\mathrm{C}_{19} \mathrm{H}_{36} \mathrm{O}_{3}$ & 312.4873 & 1.95 & - & - \\
\hline 4. & 2-Undecenal & $\mathrm{C}_{11} \mathrm{H}_{20} \mathrm{O}$ & 68.27960 & 1.78 & 2.66 & - \\
\hline 5. & Nonane,5-methyl -5-propyl & $\mathrm{C}_{10} \mathrm{H}_{22}$ & 142.284 & 1.23 & - & - \\
\hline 6. & Pentadecane,2,6,10,14-tetramethyl -(CAS) & $\mathrm{C}_{19} \mathrm{H}_{40}$ & 268.5209 & 5.03 & - & - \\
\hline 7. & Hexadecan2,6,10,14-tetramethyl-(CAS) & $\mathrm{C}_{20} \mathrm{H}_{42}$ & 282.55 & 18.54 & 6.83 & 27.71 \\
\hline 8. & Eicosane (CAS & $\mathrm{C}_{20} \mathrm{H}_{24}$ & 282.55 & 1.53 & 1.17 & - \\
\hline 9. & 6-Tridecanol,3,9-diethyl- (CAS) & $\mathrm{C}_{17} \mathrm{H}_{36} \mathrm{O}$ & 256.5 & 2.72 & - & - \\
\hline 10. & Heptadecane,8-methyl- (CAS) & $\mathrm{C}_{18} \mathrm{H}_{38}$ & 254.5 & 2.31 & - & - \\
\hline 11. & Tetratriacontane (CAS) & $\mathrm{C}_{34} \mathrm{H}_{70}$ & 478.9 & 2.25 & 1.87 & 2.49 \\
\hline 12. & Dotriacontane (CAS) & $\mathrm{C}_{32} \mathrm{H}_{66}$ & 450.8664 & 6.91 & - & 8.85 \\
\hline 13. & Pentadecanoic acid (CAS) & $\mathrm{C}_{15} \mathrm{H}_{30} \mathrm{O}_{2}$ & 242.4 & 2.55 & - & - \\
\hline 14. & Tetracosane (CAS) & $\mathrm{C}_{24} \mathrm{H}_{50}$ & 338.7 & 6.30 & - & 9.56 \\
\hline 15. & 9-Octadecenoicacid(Z)- (CAS) & $\mathrm{C}_{19} \mathrm{H}_{36} \mathrm{O}_{2}$ & 296.49 & 7.70 & 7.41 & 9.91 \\
\hline 16. & $\begin{array}{l}\text { Tetracosane,2,6,10,15,19,23-hexamethyl- } \\
\text { (CAS) }\end{array}$ & $\mathrm{C}_{30} \mathrm{H}_{62}$ & 422.8133 & 3.47 & 0.90 & - \\
\hline 17. & 1-(3',5'-Dimethylphenyl)cosan-3,5,7-triol & $\mathrm{C}_{19} \mathrm{H}_{24} \mathrm{O}_{2}$ & 284.4 & 1.54 & - & - \\
\hline 18. & Tetrapentacontane & $\mathrm{C}_{54} \mathrm{H}_{110}$ & 759.4 & 1.31 & - & - \\
\hline 19. & $\begin{array}{l}\text { Hexadecanoicacid,2-hydroxy-1- } \\
\text { (hydroxymethyl }\end{array}$ & $\mathrm{C}_{19} \mathrm{H}_{38} \mathrm{O}_{4}$ & 330.5026 & 12.43 & 11.52 & 4.36 \\
\hline 20. & Nonanal (CAS) & $\mathrm{C}_{9} \mathrm{H}_{18} \mathrm{O}$ & 142.24 & - & 1.28 & - \\
\hline 21. & $\begin{array}{l}\text { 1-Hexanol,5-methyl-2-(1-methylethyl)- } \\
\text { (CAS) }\end{array}$ & $\mathrm{C}_{10} \mathrm{H}_{22} \mathrm{O}$ & 158.28 & - & 1.19 & - \\
\hline 22. & Octacosane (CAS) & $\mathrm{C}_{28} \mathrm{H}_{58}$ & 394.76 & - & 2.88 & - \\
\hline 23. & Tetradecane (CAS) & $\mathrm{C}_{14} \mathrm{H}_{30}$ & 198.394 & - & 1.19 & - \\
\hline 24. & Isochiapin B & $\begin{array}{l}\mathrm{C} 19 \mathrm{H} 26 \mathrm{O} \\
6\end{array}$ & 350.4 & - & 5.11 & - \\
\hline 25. & Hentriacontane & $\mathrm{C}_{31} \mathrm{H}_{64}$ & 436.85 & - & 0.86 & - \\
\hline 26. & Docosan & $\mathrm{C}_{22} \mathrm{H}_{46}$ & 310.6 & - & 8.1 & - \\
\hline 27. & $\begin{array}{l}\text { 1,2-Benzenedicarboxylic } \\
\text { acidBIS,(trimethylsilyl) ester }\end{array}$ & $\begin{array}{l}\mathrm{C}_{14} \mathrm{H}_{22} \mathrm{O}_{4} \\
\mathrm{Si}_{2}\end{array}$ & 310.49 & - & 1.35 & - \\
\hline 28. & Tridecanoic acid (CAS) & $\mathrm{C}_{13} \mathrm{H}_{26} \mathrm{O}_{2}$ & 214.34 & - & 5.27 & - \\
\hline 29. & $\begin{array}{l}\text { 1,2-Benzenedicarboxylic acid, diisononyl } \\
\text { ester }\end{array}$ & $\mathrm{C}_{26} \mathrm{H}_{42} \mathrm{O}_{4}$ & 418.6 & - & 3.8 & - \\
\hline 30. & 2,3-Epoxycholestane,3-phenyl- & $\mathrm{C}_{33} \mathrm{H}_{50} \mathrm{O}$ & 462.7 & - & 1.8 & - \\
\hline 31. & $\begin{array}{l}\text { 2,5-Cyclohexadiene-1,4-dione,2,6-bis(1,1- } \\
\text { dimethyl). }\end{array}$ & $\mathrm{C}_{14} \mathrm{H}_{20} \mathrm{O}_{2}$ & 220.3074 & - & - & 2.8 \\
\hline 32. & 7-Hexyltridecan-1-ol & $\mathrm{C}_{19} \mathrm{H}_{40} \mathrm{O}$ & 284.5 & - & - & 2.75 \\
\hline 33. & $\begin{array}{l}\text { 1,2-Benzenedicarboxylic acid, butyl 2- } \\
\text { methylpropyl }\end{array}$ & $\mathrm{C}_{16} \mathrm{H}_{22} \mathrm{O}_{4}$ & 278.3435 & - & - & 2.66 \\
\hline 34. & Tetracontane & $\mathrm{C}_{40} \mathrm{H}_{82}$ & 563.1 & - & - & 2.50 \\
\hline 35. & Hexatriacontane & $\mathrm{C}_{36} \mathrm{H}_{74}$ & 506.973 & - & - & 4.74 \\
\hline 36. & Octadecamdftethylcyclononasiloxae & $\begin{array}{l}\text { C18H54O } \\
9 \mathrm{Si9}\end{array}$ & 667.4 & - & - & 2.57 \\
\hline 37. & Eicosamethylcyclodecasiloxane & $\begin{array}{l}\mathrm{C}_{20} \mathrm{H}_{60} \mathrm{O}_{10} \\
\mathrm{Si}_{10}\end{array}$ & 741.55 & - & - & 9.23 \\
\hline - & Means Not detected & & & $\% 100$ & $\% 100$ & $\% 100$ \\
\hline
\end{tabular}


The most available organic class compounds of Reandy genotype were hydrocarbon, terpenoid and fatty acid accounting for $80.37 \%$ of total seed oil contents figure (4). The relative abundance of terpenoids and hydrocarbons were significantly higher in Reandy genotype in compare with sultan and Heros genotypes, which make it better choice for cultivation by plant breeders as a rich plant oil yields to be used in adverse fields of industry. Our finding agreed by previous research article concluding that the Reandy variety possess high crop plant yields with maximum seed oil efficiency (Abdulkhaleq et al., 2018). It could be cultivated as edible and industrial oils as well as for animal feed that's why many protocols have applied brassica seed oils to improve its agronomic features (Boulter et al., 1990).

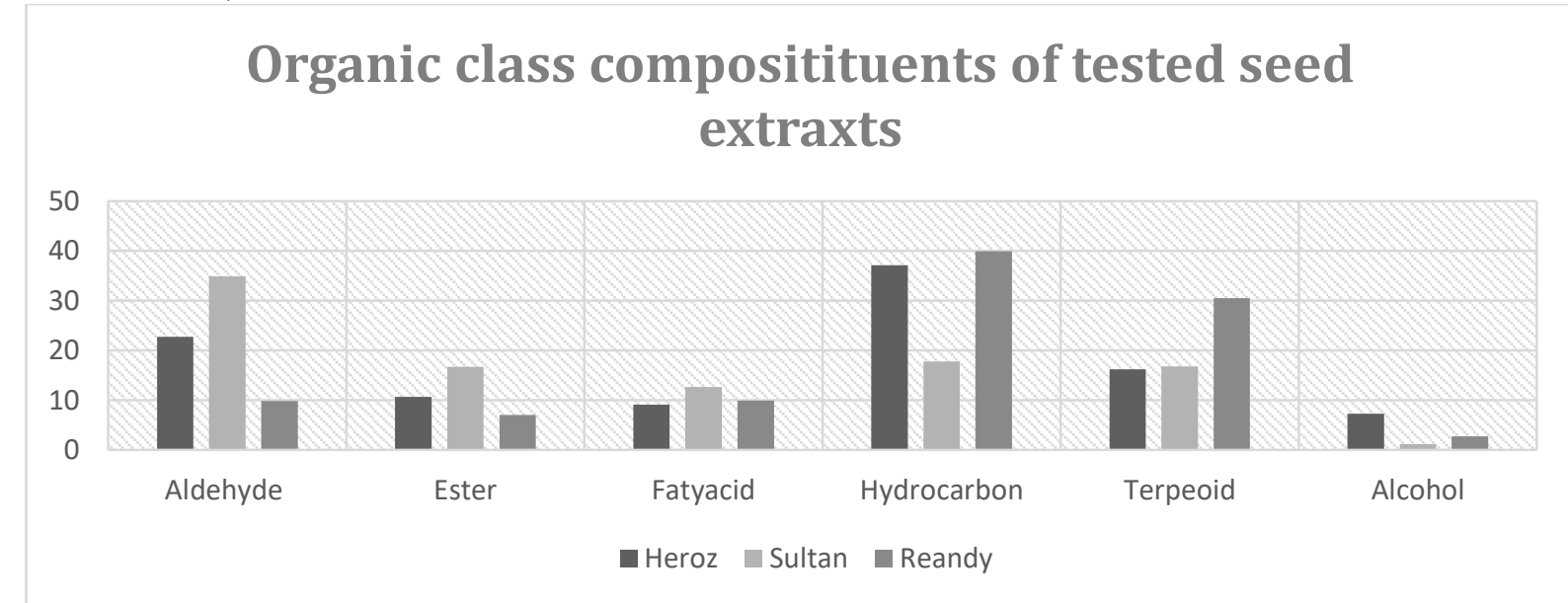

Figure 4. Shows the differential percentages (Y-axis) of organic class contents (X-axis) of three tested cultivars of brassica napus.

The hydrocarbon fraction accounted for 39.91, 37.09 and $17.78 \%$ for the Reandy, Heros and Sultan, respectively Table (2). Tetratriacontane (CAS) and Tetracosane (CAS) were the most common hydrocarbon in all three varieties. Role of these hydrocarbons has already been explained by a recent published research article (Uttamaprakrom et al., 2017). This high hydrocarbon contents of B. napus cultivars allow them to possess the fuel properties as the have numerous ester compounds, the beneficial B. napus plant as biofuel in biodiesel industry has also been proved by a team of researchers (Solis et al., 2017). The Ester fraction accounted for $16.67,10.65$ and $7.05 \%$ for the Sultan, Heros and Reandy, respectively. The most available ester in all three mentioned varieties was found to be Hexadecanoic acid, 2-hydroxy-1-(hydroxymethyl) ethyl ester, a derivative of palmitin. Other fatty acids which we found to be exist in the tested seed oils were oleic acid, pentadecanoic acid and tridecanoic acids which they could be used in industrial production (Anwar et al., 2017).

Same class of fatty acids were found in B. napus by (Graef et al., 2009), they were clearly showed the suitability of brassica napus oils in biodiesel production. The Percentage content of terpenoids were $30.55,16.77$ and $16.24 \%$ for the Heros, sultan and Reandy, respectively Table (2). The most available terpenoid in all three experimented seeds was Phytan (Hexadecan2,6,10,14-tetramethyl), a long chain 
Mesopotamia J. of Agric.

Vol. (48) No. (3) 2020
ISSN: 2224 - 9796 (Online)

ISSN: 1815 - $316 \mathrm{X}$ (Print)

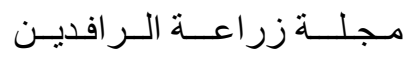

المجلد (48) العدد (3) 2020

Table (2) : different organic class contents three experimented genotypes of $B$. napus.

\begin{tabular}{|c|c|c|c|c|c|c|c|}
\hline $\begin{array}{l}\mathrm{N} \\
\mathrm{o}\end{array}$ & $\begin{array}{l}\text { Organic } \\
\text { class }\end{array}$ & $\begin{array}{l}\text { Heros organic } \\
\text { content }\end{array}$ & $\begin{array}{c}\text { Class } \\
\%\end{array}$ & $\begin{array}{l}\text { Sultan organic } \\
\text { content }\end{array}$ & $\begin{array}{c}\text { Class } \\
\%\end{array}$ & $\begin{array}{c}\text { Reandy organic } \\
\text { content }\end{array}$ & $\begin{array}{c}\text { Class } \\
\%\end{array}$ \\
\hline 1. & Aldehyde & $\begin{array}{l}\text {-2-decenal,E- } \\
\text { (CAS) } \\
\text {-2,4-Decadinal, } \\
\text { (E,E)-(CAS) } \\
\text {-2-Undecenal }\end{array}$ & $\begin{array}{c}22.7 \\
6\end{array}$ & $\begin{array}{c}\text {-Nonanal (CAS) } \\
\text {-2-Decenal, (E)- } \\
\text { (CAS) } \\
\text {-2,4 Decadinal } \\
\text { (E,E)- (CAS) } \\
\text {-2-Undecenal }\end{array}$ & $\begin{array}{c}34.9 \\
1\end{array}$ & $\begin{array}{l}\text { - 2,4-Decadinal, } \\
\text { (E,E)- (CAS) }\end{array}$ & 9.86 \\
\hline 2. & Ester & $\begin{array}{l}\text { Octadecanicacid,2 } \\
\text {-oxo-methyl } \\
\text { ester(CAS) } \\
\text { Hexadecanoic } \\
\text { acid, hydroxy-1- } \\
\text { (hydroxymethyl } \\
\text {-Hexadecanoic } \\
\text { acid,2hydroxy-1- } \\
\text { (hydroxymethy }\end{array}$ & $\begin{array}{c}10.6 \\
5\end{array}$ & $\begin{array}{l}\text { 1,2Benzenedicarbo } \\
\text { xylic acid } \\
\text { BIS,(trimethylsilyl) } \\
\text { ester-1,2- } \\
\text { Benzenedicarboxyli } \\
\text { c acid } \\
\text { diisononyl ester } \\
\text { - } \\
\text { Hexadecanoicacid, } \\
\text { 2- hydroxy-1 } \\
\text { (hydroxymethyl)eht } \\
\text { yl }\end{array}$ & $\begin{array}{c}16.6 \\
7\end{array}$ & $\begin{array}{l}\text {-Hexadecanoic } \\
\text { acid,2-hydroxy-1- } \\
\text { (hydroxymethyl)e } \\
\text { thyl ester -1,2- } \\
\text { Benzenedicarbox } \\
\text { ylic acid, butyl 2- } \\
\text { methylpropyl. }\end{array}$ & 7.02 \\
\hline 3. & $\begin{array}{l}\text { Fatty } \\
\text { acids }\end{array}$ & $\begin{array}{l}\text { - Pentadecanoic } \\
\text { acid (CAS) } \\
\text {-9-Octadecenoic } \\
\text { acid (Z)- }\end{array}$ & 9.07 & $\begin{array}{c}\text {-Tridecanoic acid } \\
\text { (CAS) } \\
\text {-9-Octadecenoic } \\
\text { acid (Z)- }\end{array}$ & $\begin{array}{c}12.6 \\
8\end{array}$ & $\begin{array}{l}\text {-9-Octadecenoic } \\
\operatorname{acid}(\mathrm{Z})-\end{array}$ & 9.91 \\
\hline 4. & $\begin{array}{l}\text { Hydrocarb } \\
\text { on }\end{array}$ & $\begin{array}{l}\text { Nonane,5-methyl } \\
\text {-5-propyl } \\
\text { Eicosane (CAS) } \\
\text { Heptadecane,8- } \\
\text { methyl- (CAS) } \\
\text { Tetratriacontane } \\
\text { (CAS) } \\
\text { Dotriacontane } \\
\text { (CAS) } \\
\text { Tetracosane } \\
\text { (CAS) } \\
\text { Tetrapentacontane }\end{array}$ & $\begin{array}{c}37.0 \\
9\end{array}$ & $\begin{array}{l}\text { Octacosane (CAS) } \\
\text {-Tetradecane } \\
\text { (CAS) } \\
\text {-Hentriacontane } \\
\text {-Eicosane } \\
\text {-Docosane (CAS) } \\
\text {-Docosane (CAS) } \\
\text {-Tetratriacontane } \\
\text { (CAS) } \\
\text {-Docosane (CAS)- } \\
\text { 2,3Epoxycholestan } \\
\text { e,3-phenyl }\end{array}$ & $\begin{array}{c}17.7 \\
8\end{array}$ & $\begin{array}{l}\text { Tetracontane,Tetr } \\
\text { atriacontane, - } \\
\text { Dotriacontane } \\
\text { Tetracosane } \\
\text {-Hexatriacontane- } \\
\text { Cyclononasiloxan } \\
\text { e,octadecamet,Eic } \\
\text { osamethylcyclode } \\
\text { casiloxane,2,5- } \\
\text { Cyclohexadiene- } \\
\text { 1,4-dione,2,6- } \\
\text { bis(1,1-dimethyl) }\end{array}$ & 39.91 \\
\hline 5 & $\begin{array}{l}\text { Terpenoid } \\
\mathrm{s}\end{array}$ & $\begin{array}{l}\text { Pentadecane, } 2,6,1 \\
0,14 \text {-tetramethyl - } \\
\text { (CAS) } \\
\text { Hexadecan2,6,10, } \\
\text { 14-tetramethyl }\end{array}$ & $\begin{array}{c}16.2 \\
4\end{array}$ & $\begin{array}{c}\text {-Isochiapin B } \\
\text { Hexadecane,2,6,10, } \\
\text { 14-tetramethyl- } \\
\text { (CAS) }\end{array}$ & $\begin{array}{c}16.7 \\
7\end{array}$ & $\begin{array}{l}\text { Hexadecane, } 2,6,1 \\
0,14 \text {-tetramethyl- } \\
(\mathrm{CAS})\end{array}$ & 30.55 \\
\hline 6 & Alcohol & $\begin{array}{c}\text { - Hexyltridecan- } \\
\text { 1-ol } \\
\text {-6-Tridecanol, } \\
\text { 3,9-diethyl- } \\
\text { (CAS) } \\
\text {-1-(3',5'- } \\
\text { Dimethylphenyl) } \\
\text { cosan-3,5,7-triol }\end{array}$ & 7.33 & $\begin{array}{l}\text { 1-Hexanol,5- } \\
\text { methyl-2-(1- } \\
\text { methylethyl)- } \\
\text { (CAS) }\end{array}$ & 1.19 & $\begin{array}{l}\text {-7-Hexyltridecan- } \\
\text { 1-ol }\end{array}$ & 2.75 \\
\hline
\end{tabular}


Mesopotamia J. of Agric.

Vol. (48) No. (3) 2020
ISSN: 2224 - 9796 (Online)

ISSN: 1815 - $316 \mathrm{X}$ (Print)
مـلــــة زر اعـــة الــر افديـن

المجلد (48) العدد (3) 2020

alkane with fuel like odor considered as natural compound source in the biofuel production (Kuppusamy et al., 2020).

Furthermore, phytochemicals like Octadecamethyl-cyclononasiloxane, has been used in cosmetics (Mackay et al., 2015), 1,2-Benzenedicarboxylic acid, diisononyl ester known as plasticizer (Earls et al., 2003) and 2,4,10,15,19,23 Hexamethyl tetracosane known as squalene rolling as antimicrobials were also detected in the tested varieties (Cui et al., 1997). Many other compounds mentioned in table (1) are not discussed here. In general, various cultivars had different photochemical constituents that may form their basis of genotype selection.

\section{CONCLUSION}

The oils extracted by n-hexane from Heros, sultan and Reandy seed cultivars of Brassica napus were shown to be effective method for phytochemical detections by GCMS. Despite their originality of cultivated and analyzed plant seeds, they shared significant differences in their phytochemical contents along with their variabilities in terms of plant oil yields, which may due to demographic, metabolic differences or defense system. To fulfill with the increased demand for the biofuel production as petro fuel alternatives, the presented seed genotypes can be considered as rich source of hydrocarbon plant yields to be cultivated in vast areas in which its soil not suitable for agriculture of edible plants (A soil which is rich in organic matters like cadimium and lead). Depending on the given data, it can be proposed that all three seed cultivars can offer good hydrocarbon plant yields with Heros and Reandy genotypes to be more efficient for the petro forming like biodiesel as low emission renewable energy. A palmitin oil precursor called Hexadecanoic acid, 2-hydroxy-1-(hydroxymethyl) ethyl ester was found as the most abundant ester which was well known for its nutritional values. Oleic acid was the predominant fatty acids in all three experimented plant seeds, which rises new interest to investigate the edibility properties of those seed oils and to adopt new methods in developing seeds with maximum seed oil edibility and minimum toxicity.

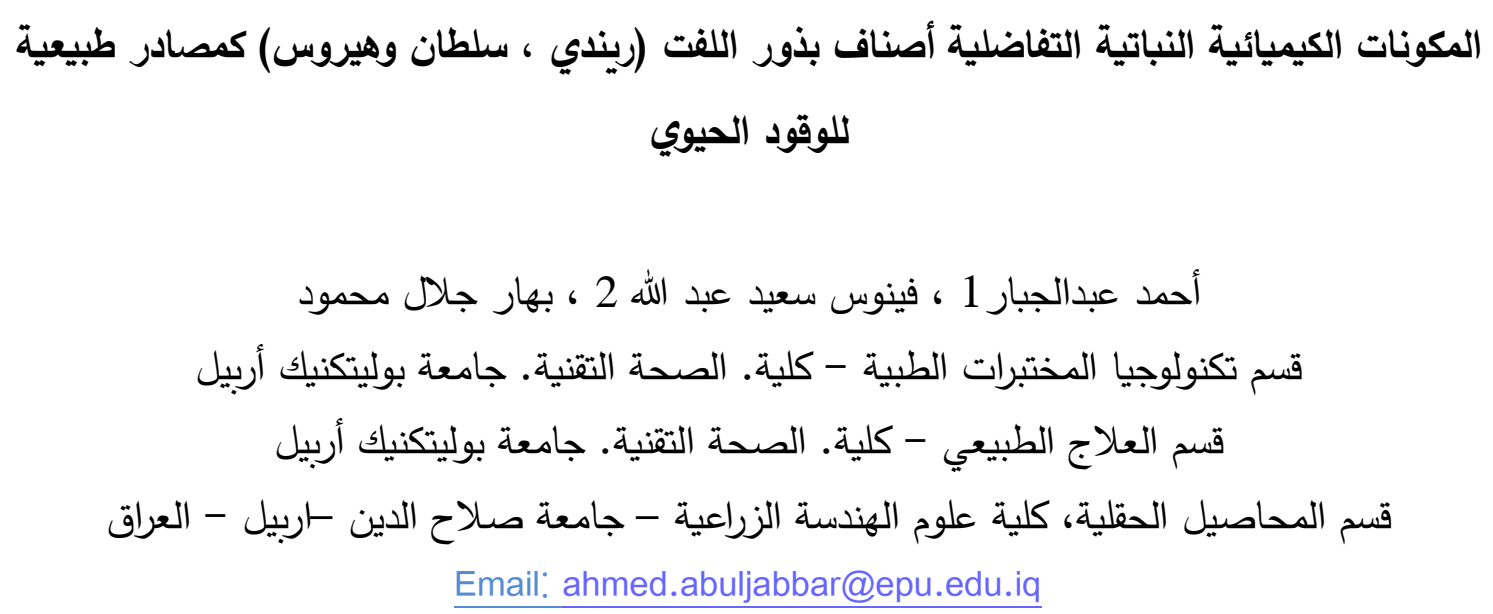


Mesopotamia J. of Agric.

Vol. (48) No. (3) 2020
ISSN: 2224 - 9796 (Online)

ISSN: 1815 - $316 \mathrm{X}$ (Print)

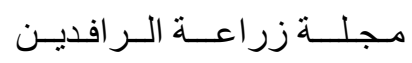
المجلد (48) العدد (3) 2020

\section{الخلاصة}

يهدف العمل الحالي إلى استكثاف أصناف لثلاثة من بذور كانولا (اللفت) ، بالإضافة إلى محاولة

توفير نظرة ثاقبة كيميائية نباتية لأصناف مختلفة من بذور اللفت يمكن زراعتها كمصادر هيدروكربونية بديلة طبيعية لهيدروكربونات البترول. تم شراء البذور للطرز الثلاثة Heros، Sultan و Reandy من بريطانيا والهند والسويد ، على التوالي. بعد الزراعة ، تم جمع البذور وتجفيفها وسحقها. تم استخلاص الزيوت من البذور المطحونة باستخدام n-hexane كمذيب ، وتم تحليل الزيوت الناتجة بواسطة GC-MS. أظهرت النتائج أن البذور الزيتية المختبرة أظهرت مكونات كيميائية نباتية ذات قيمة عالية ، تمتلك نسبًا متزايدة من ون الهيدروكربونات طويلة السلسلة. كان 4، Decadinal (E -2، هو المركبات الكيميائية النباتية المتفوقة في زيوت بذور Heros (18.73\%) وزيوت السلطان (29.35\%) ، ومع ذلك ، فقد كان ثاني مركب سائد في زيوت بذور Reandy. كما كانت النسبة المئوية لمحتوى الهيدروكربونات في التركيب الوراثي لبذور الرياني أعلى بنسبة (39.91\%) من تلك الموجودة في زيوت بذور السلطان (17.78\%). تبين أن الأحماض الدهنية الأكثر انتثارًا هي حمض Octadecenoic-9 جميع العناصر الثلاثة المختبرة. بناءً على البيانات التي تم الحصول عليها ، يمكن تقديم غلة جيدة من نباتات الهيدروكارب بواسطة أصناف Heros و reandy. أيضًا كزيت بذرة ، يمكن اعتباره زيت نباتي فعال للاستخدام الصناعي مثل الزيوت غير الصالحة للأكل لإنتاج الديزل الحيوي كطاقة متجددة منخفضة الانبعاثات. الكلمات المفتاحية: بذوركانولا، المركبات العضوية الثانوية، الطاقة المتجددة، GC-MS.

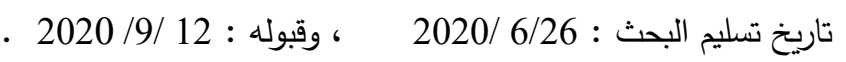

\section{REFERENCES}

Abas, N., Kalair, A., and Khan, N. (2015). Review of fossil fuels and future energy technologies. Futures, 69, 31-49.

Abdulkhaleq, D. A. A., Hama, S. J. H., and Ahmad, R. M. A. (2018). Response of some Rapeseed (Brassica napus L.) varieties to $\mathrm{Zn}$ fertilizer under dry farming conditions. Zankoy Journal of Sulaimani, 10(2): 166-177.

Abdullah, A.O., Sirwan, T.S and Bahar, J.M. (2019). Some Characters of Different Genotypes of Brassica napus in Erbil City-Kurdistan Region-Iraq.

Anwar, F., Rashid, U., Ashraf, S., Al-Resayes, S. I., Mehmood, M. A., Nehdi, I. A., Ibrahim, M., and Hanif, M. A. (2017). Biodiesel synthesis from Brassica napus seed oil using statistical optimization approach. Journal of Renewable and Sustainable Energy, (9): 013103.

Boszoradova, E., Libantova, J., Matusikova, I., Poloniova, Z., Jopcik, M., Berenyi, M., and Moravcikova, J. (2011). Agrobacterium-mediated genetic transformation of economically important oilseed rape cultivars. Plant Cell, Tissue and Organ Culture, 107(2):317-323.

Boulter, M. E., Croy, E., Simpson, P., Shields, R., Croy, R. R. D., \& Shirsat, A. H. (1990). Transformation of Brassica napus L. (oilseed rape) using 
Agrobacterium tumefaciens and Agrobacterium rhizogenes- A comparison. Plant Science, 70(1): 91-99.

Cartea, E., De Haro-Bailón, A., Padilla, G., Obregón-Cano, S., Del Rio-Celestino, M., and Ordás, (2019). Seed oil quality of brassica napus and Brassica rapa germplasm from Northwestern Spain. Foods journal, 27(8):292.

Cui, S. T., Cummings, P. T., \& Cochran, H. D. (1997). Configurational bias Gibbs ensemble Monte Carlo simulation of vapor-liquid equilibria of linear and shortbranched alkanes. Fluid Phase Equilibria, 141(1-2): 45-61.

Değirmenci, H., and Erkurt, H. (2020). Relationship between volatile components, antimicrobial and antioxidant properties of the essential oil, hydrosol and extracts of Citrus aurantium L. flowers. Journal of Infection and Public Health, 13(1): 58-67.

Earls, A. O., Axford, I. P., and Braybrook, J. H. (2003). Gas chromatography-mass spectrometry determination of the migration of phthalate plasticisers from polyvinyl chloride toys and childcare articles. Journal of Chromatography A, 983(1-2):237-46.

Friedt, W., and Snowdon, R. (2009). "Oilseed rape," in Handbook of Plant Breeding. Oil Crops Breeding, eds J. Vollmann and R. Istvan (New York, NY: Springer). Vol.4, pp 91-126..

Fu, W. J., Chi, Z., Ma, Z. C., Zhou, H. X., Liu, G. L., Lee, C. F., and Chi, Z. M. (2015). Hydrocarbons, the advanced biofuels produced by different organisms, the evidence that alkanes in petroleum can be renewable. Applied Microbiology and Biotechnology, (99): 7481-7494.

Graef, G., Lavallee, B. J., Tenopir, P., Tat, M., Schweiger, B., Kinney, A. J., Van Gerpen, J. H., and Clemente, T. E. (2009). A high-oleic-acid and low-palmiticacid soybean: Agronomic performance and evaluation as a feedstock for biodiesel. Plant Biotechnology Journal, 7(5):411-21.

Jayalakshmi, M., Vanitha, V., and Sangeetha, R.(2018). Determination of phytocomponents in ethanol extract of Brassica oleracea using gas chromatography-mass spectroscopy technique. Asian Journal of Pharmaceutical and Clinical Research, 11(10): 133-136.

Jianmei, C., Hangru, H. A. N., Rongzhan, G., and Weicong, Q. I. (1997). Studies on volatile compounds of different varieties in Brassica napus L. Quality Analysis and Nutrition, 3(2): 109-112.

Kaiani, K. A., Abduljabbar, A. A., and Mustafa, M. A. (2019). The Effect of Heat Stress on Oxidative Stress and Antioxidant Status in Local Quail Hens Supplemented with Onion and Garlic Oils. Tikrit Journal of Agriculture Science, 19(1), 103-110. http://dx.doi.org/10.25130/tjas.v19i1

Kalita, D.(2008). Hydrocarbon plant-New source of energy for future. Renewable and Sustainable Energy Reviews, 12(2): 455-471.

Kuppusamy, S., Maddela, N. R., Megharaj, M., Venkateswarlu, K., Kuppusamy, S., Maddela, N. R., Megharaj, M., and Venkateswarlu, K.(2020). An Overview of Total Petroleum Hydrocarbons. In Total Petroleum Hydrocarbons. New York, NY: Springer. Vol.1.pp 1-27.

Mackay, D., Cowan-Ellsberry, C. E., Powell, D. E., Woodburn, K. B., Xu, S., Kozerski, G. E., and Kim, J. (2015). Decamethylcyclopentasiloxane (D5) 
environmental sources, fate, transport, and routes of exposure. Environmental Toxicology and Chemistry, 34(12):2689-2702.

Naghavi, M. R., Marouf, K., and Aboughadareh, A. P. (2015). Effect of water deficit stress on yield and yield components of canola (Brassica napus L.) cultivars. Tahran: International Journal of Agronomy and Agricultural Research, 7(2): 8-13.

Senthilkumar, N., Murugesan, S., and Vijayalakshmi, K. B.(2012). GC-MS-MS analysis of Trichilia connaroides (Wight \& amp; Arn.) Bentv (Meliaceae): A tree of ethno botanical records. Asian Journal of Plant Science and Research, 2(2): 193-197.

Sharma, A., Kumar, V., Kanwar, M. K., Thukral, A. K., and Bhardwaj, R. (2017). Phytochemical profiling of the leaves of Brassica juncea L. using GC-MS. International Food Research Journal, 24(2): 547-551.

Solis, J. L., Berkemar, A. L., Alejo, L., and Kiros, Y. (2017). Biodiesel from rapeseed oil (Brassica napus) by supported $\mathrm{Li}_{2} \mathrm{O}$ and $\mathrm{MgO}$. International Journal of Energy and Environmental Engineering, (8): 9-23.

Soodabeh Saeidnia. (2012). Importance of Brassica napus as a medicinal food plant. Journal of Medicinal Plants Research, 6(14):2700-2703.

Sparkman, O. D.(2005). Identification of essential oil components by gas chromatography/quadruple mass spectroscopy Robert P. Adams. Journal of the American Society for Mass Spectrometry, 8(6): 671-672.

Talbot, G. (2015). Specialty Oils and Fats in Food and Nutrition: Properties, Processing and Applications.(1 ${ }^{\text {st }}$ Edition). Woodhead Publishing. Newyork.pp.349-357.

Uttamaprakrom, W., Reubroycharoen, P., Vitidsant, t., and Charusiri, V. (2017). Catalytic degradation of rapeseed (Brassica napus) oil to a biofuel using MgO: an optimization and kinetic study. Journal of the Japan Institute of Energy, 96(6): 190-198.

Verran, J., Redfern, J., Burdass, D., and Kinninmonth, M. (2014). Using soxhlet ethanol extraction to produce and test plant material (essential oils) for their antimicrobial properties. Journal of Microbiology \& Biology Education, 15(1): 45-46.

Yeddes, N., Chérif, J. K., Jrad, A., Barth, D., and Trabelsi-Ayadi, M. (2012). Supercritical SC-CO $\mathrm{CO}_{2}$ and Soxhletn-Hexane Extract of Tunisian Opuntia ficusindica seeds and fatty acids analysis. Journal of Lipids, 1-6. 